\title{
Democracia: estado idílico da política?
}

Giorgio AGAMBEN; Alain BADIOU; Daniel BENSAÏD; Wendy BROWN; Jean-Luc NANCY; Jacques RANCIÈRE; Kristin ROSS e Slavoj ŽIŽEK. Démocratie, dans quel état? Paris, La Fabrique, 2009. 151 páginas.

\section{Orlando Villas Bôas Filho}

A democracia parece gozar de um consenso sem precedentes na atualidade. Ainda que tomada a partir de diversos matizes, é incontestável que, de um modo geral, atribui-se a ela um valor positivo. Porém, em que consiste efetivamente a democracia hoje? Haveria algum sentido capaz de delimitar seu contorno conceitual? Se sim, qual seria esse contorno? Essas questôes fundamentam as análises realizadas na obra coletiva intitulada Démocratie, dans quel état?, composta de oito perspectivas distintas que, embora não rejeitem a democracia, são profundamente críticas em relação ao seu uso retórico e despolitizado. ${ }^{1}$

No primeiro capítulo, intitulado "Note liminaire sur le concept de démocratie", Giorgio Agamben ressalta que o discurso político sobre o termo "democracia” seria falseado por uma anfibologia preliminar que conduziria a mal-entendidos, motivo pelo qual caberia indagar à qual racionalidade esse termo remete. Segundo Agamben, o debate atual acerca da democracia a concebe como uma forma de constituição do corpo político e como uma técnica de governo. Nesse sentido, o termo remeteria, simultaneamente, para uma conceituação de direito público e para uma prática administrativa, pois designaria tanto a forma de legitimação do poder político como as modalidades de seu exercício. Para Agamben, o entrelaçamento dessas duas conceituações - a jurídico-política e a econômico-gestacional - teria raízes profundas que dificultariam sua distinção. Segundo ele, a palavra politeia, por exemplo, que aparece nos clássicos do pensamento político grego, sobretudo no contexto da discussão de suas diferentes formas, é traduzida tanto por "constituição" como por "governo". Porém, de onde proviria o caráter ambíguo desse conceito político fundamental? Utilizando, como exemplo, uma passagem da Política (1279a) 
de Aristóteles e outra do Contrato social de Rousseau, Agamben, a partir dos conceitos de kyrion e souveraineté, procura indicar o nó indissolúvel existente entre constituição e governo. Enfatiza, assim, que o malentendido consistente em conceber o governo como simples poder executivo engendraria um dos equívocos de implicações mais pesadas da história política ocidental, pois faria com que a reflexão política se extraviasse em abstrações vazias tais como "lei", "vontade geral" e "soberania popular", deixando sem resposta a questão fundamental relativa à articulação entre governo e soberano.

Alain Badiou, no capítulo intitulado "L'emblème démocratique", afirma que a democracia figura como o emblema dominante da sociedade política contemporânea. Nesse sentido, enfatiza a necessidade, ainda que a título de um exercício a priori, de destituir as sociedades desse emblema para melhor se aproximar de sua realidade. Assim, inicia sua análise ressaltando o caráter circunscrito assumido pela democracia, pois o "mundo" dos "democratas", na prática, não se estenderia a todos, o que tornaria seus componentes, na verdade, uma elite conservadora ("Democratie, oui, mais réservée aux démocrates, n'est-ce pas?", p. 16). Propõe, desse modo, uma releitura daquilo que considera ser, no âmbito da filosofia, a primeira destituição do emblema democrático: o livro VIII da República, no qual Platão denomina "democracia" a um tipo de constituição. Não há como reproduzir aqui a análise feita por Badiou acerca da crítica que Platão endereça à democracia. $\mathrm{O}$ que importa notar é que, segundo esse autor, a crítica platônica não seria simplesmente reativa e aristocrática. Assim, recuperando o essencial do argumento de Platão, ao qual adere expressamente, Badiou ressalta que o mesmo se prestaria à compreensão e à crítica da democracia nas sociedades atuais.

Em seguida, em "Le scandale permanent", Daniel Bensaïd ressalta que, com o fracasso do despotismo burocrático e do socialismo inexistente, a democracia teria se tornado sinônimo do Ocidente vitorioso, caracterizado por Estados triunfantes, mercado livre e concorrência, ao mesmo tempo em que ocorreria um ataque maciço contra as solidariedades e os direitos sociais e uma ofensiva sem precedente de privatização do mundo que esvaziaria o sentido da esfera pública. Assim, segundo ele, estaria se confirmando o receio de Hannah Arendt de ver a política, como pluralidade conflituosa, ser substituída por uma gestão prosaica de coisas e pessoas. Ressalta, entretanto que, uma vez que a democracia não pode ser associada apenas ao livre comércio e à livre circulação do capital, posto ser expressão de um inquietante princípio igualitário, seu efetivo triunfo, sobretudo diante das investidas ameaçadoras da antipolítica e da despolitização, implicaria a afirmação de sua dimensão propriamente política.

Bensaïd procura, assim, abordar a questão da representação na democracia. Opondo-se à concepção de Rancière, ${ }^{2}$ para quem a representação constituiria uma forma de oligarquia, procura ressaltar, baseando-se sobretudo em Castoriadis e Lefort, a necessidade da representação diante da heterogeneidade irredutível da sociedade e da pluralidade desarticulada dos espaços e tempos sociais. Porém, enfatiza a necessidade de existência da esfera pública para que a representação não se torne uma simples farsa. Partindo da premissa de que a representação é inevitável, ressalta a necessidade de procurar os meios que garantam sua efetividade. Criticando particularmente a perspectiva de Simone Weil, observa que, embora seja legítimo desconfiar das lógicas partidárias, não se pode imputar à forma partidária a responsabilidade exclusiva pela burocratização e demais mazelas. Assim, a supressão dos partidos, propugnada por Weil, conduziria a um fetichismo invertido que, a partir de um determinismo organizacional, naturalizaria a organização em vez de historicizá-la.

Em "Nous sommes tous démocrates à présent", Wendy Brown ressalta que a democracia teria se tornado um "significante vazio", que serviria de arrimo a quaisquer sonhos e esperanças, motivo pelo qual caberia perguntar o que dela resta efetivamente. Nesse sentido, a autora inicia sua análise observando que a democracia liberal, forma dominante da modernidade ocidental, consistiria numa variante dentre os diversos modos de partilha do poder político, compreendidos no termo grego "Demos + cracia" que expressa o governo do povo sobre si mesmo. Definida nesses termos, a democracia constituiria um princípio incompleto, pois não indicaria quais poderes deveriam ser partilhados, nem como o poder do povo deveria ser organizado ou por quais instituiçôes deveria ser estabelecido e assegurado. 
Ademais, segundo Brown, haveria um esvaziamento do conteúdo da democracia pois, mesmo diante do entusiasmo que lhe é dispensado atualmente, o que paradoxalmente se observa seria justamente uma progressiva erosão de sua substância. Esse processo de "desdemocratização" (dé-démocratisation) decorreria de várias causas, dentre as quais se destacariam, sobretudo, as seguintes: 1) fusão do poder de grandes grupos econômicos com o poder estatal; 2) desvirtuamento das eleições "livres" por sofisticadas campanhas de marketing; 3) adoção do neoliberalismo como expressão da racionalidade política; 4) usurpação das competências legislativas pela expansão dos tribunais nacionais e internacionais; 5) erosão da soberania nacional em virtude do processo de globalização econômica; 6) crescente imposição de políticas securitárias que, a pretexto de reprimir práticas terroristas, atentam contra os princípios liberais. ${ }^{3}$

Por fim, Wendy Brown, comparando a democracia antiga e a moderna, enfatiza que a igualdade constituía o princípio fundamental da primeira e a liberdade (como autolegislação) expressaria a essência da segunda. Por isso, o advento do sujeito moral livre, que ocorre na modernidade, teria feito da democracia a única forma política legítima no Ocidente. Ressalta, entretanto, que o simples assentimento popular às leis e aos legisladores não seria suficiente para preencher a promessa democrática de autolegislação, pois seria necessário controlar as múltiplas formas que constroem nossa subjetividade. Para ela, o pressuposto de que mundo social e nossa própria subjetividade são construtos de relações de poder que estão fora de nosso controle, por si só, solaparia a noção liberal de autolegislação. Nessa perspectiva, a implementação efetiva da democracia política implicaria desviar o foco para esses poderes que parecem ser imunes à democratização.

Em "Démocratie finie et infinie", Jean-Luc Nancy ressalta, logo de início, que a democracia teria se tornado um caso de insignificância exemplar, uma vez que, ao pretender representar a política virtuosa e a única forma de garantia do bem comum, teria acabado por elidir todo e qualquer questionamento a seu respeito. Assim, a democracia passaria a ter um alcance tão amplo - abrangendo ética, política, direito e civilização - que, em última instância, perderia completamente sua significação. Seria necessário, portanto, demarcar seus sentidos, pois a democracia designaria, de um lado, as condiçōes práticas possíveis de governo e, de outro, uma ideia de homem ou do mundo que implica a capacidade de implementação de uma autonomia integral. A partir de uma análise que se inicia recuperando a etimologia da palavra, ressalta que o sufixo "-cracia" (-cratie) remete à ideia de força e de imposição violenta, ao contrário do que ocorre com o sufixo "-arquia" (-archie) que remeteria à ideia de um poder fundado ou legitimado por um princípio. Assim, segundo sua análise, o termo democracia pareceria colocar de lado a possibilidade de um princípio fundador. Segundo Nancy, não haveria "demarquia" ("démarchie"), de modo que o povo não faz as vezes do princípio. Seria por essa razão que o direito para o qual remete a instituição democrática não se sustenta senão a partir de uma relação sempre ativa e renovada com sua carência de fundamento.

O capítulo intitulado "Les démocraties contre la démocratie" consiste numa entrevista realizada com Jacques Rancière que, nela, retoma teses desenvolvidas anteriormente em livros como La mésentente (1995), Aux bords du politique (1998) e, sobretudo, La haine de la démocratie (2005). Nesse sentido, Rancière inicia sua intervenção reiterando que a democracia não se reduz nem a uma forma de governo nem a um modo de vida social. Segundo ele, a democracia, entendida como poder do povo (ou seja, daqueles que não têm nenhum título específico para exercê-lo), constitui a própria base que torna a política pensável. Desse modo, a democracia teria uma função de legitimação e uma função crítica, pois, de um lado, permitiria legitimar os regimes políticos e, de outro, impediria que a política (politique) se transformasse simplesmente em polícia (police). Porém, segundo ele, não se pode afirmar que, atualmente, haja um consenso acerca do valor da democracia, mesmo diante de sua concepção ordinária, pois os próprios países que se dizem "democráticos" se mostrariam cada vez mais distanciados dela. O discurso dominante jogaria, a partir de diferentes maneiras, contra a democracia que, para além da polissemia que a atravessa, é, enquanto noção política, objeto de luta.

Em “Démocratie à vendre”, Kristin Ross, retomando uma colocação de Auguste Blanqui, inicia sua análise enfatizando o progressivo desmantelamento do sufrágio universal e da própria democracia repre- 
sentativa. Assim, contrapõe a concepção moderna de democracia, que a vincula à capacidade de tomada decisões coletivas pela regra da maioria, a uma concepção que, fundada em Rancière, procura resgatar seu sentido original, que consiste na capacidade de ação das pessoas ordinárias em relação às questões comuns. Seguindo Rancière, ressalta que, nessa segunda concepção, a democracia não seria uma forma de governo, nem estaria vinculada apenas à quantidade de indivíduos que exercem o poder. Referindose à origem etimológica da palavra "democracia", ressalta que a mesma, diferentemente do que ocorre com "monarquia" e "oligarquia", não estaria relacionada com o aspecto quantitativo, uma vez que o poder do demos não consistiria no poder do povo ou de sua maioria, mas, sobretudo, no poder exercido por quem não é provido de título para tanto ("le pouvoir de n'importe qui", p. 109).

Assim, a democracia consistiria num apelo à igualdade uma vez que excluiria a atribuição do exercício do poder àqueles que seriam considerados melhores, rejeitando, portanto, a cisão entre uma elite considerada apta a governar e os demais, considerados inaptos para tanto. Ressalta, porém, que esse já não seria mais o sentido da democracia, quando Blanqui, no século XIX, assinalou sua vagueza ("un mot en caoutchouc", p. 101). Aludindo ao poema Démocratie de Rimbaud, Ross ressalta que este marcaria o momento preciso em que ocorre a torção de sentido do termo democracia que, a partir de então, teria servido como uma espécie de slogan para justificar a política colonial dos "países civilizados" e sua natural propensão, supostamente a justo título, ao governo do mundo. A autora ressalta, ademais, que as democracias liberais ocidentais teriam passado a se relacionar com o consumo, tornando-se completamente despolitizadas e vividas como uma situação falsamente atemporal. Teria havido um esvaziamento do valor emancipatório que outrora caracterizava a democracia, de modo que esta teria se tornado uma ideologia de classe que apenas legitimaria sistemas governados de forma restrita e sem a efetiva participação popular. Diante disso, seria fundamental retomar o sentido original da democracia: poder de qualquer um de tomar a cargo os assuntos comuns ("pouvoir de n'importe qui de s'occuper des affaires communes", p. 120), pois assim ela expressaria a própria especificidade da política.
Intitulado "De la démocratie à la violence divine", o último capítulo da obra, de autoria de Slavoj Žižek, inicia-se, a partir de uma breve contraposição entre Lacan e Foucault, concernente à questão da relação entre saber e poder, pela indicação de que um dos impasses fundamentais da democracia contemporânea consistiria na perda de existência substancial positiva por parte do povo. Sua argumentação o conduz à questão da "violência divina", entendida, tal como a conceituou Walter Benjamin, como a suspensão político-religiosa da ética. Nesse sentido, Žižek, aludindo a Franz Fanon e Hegel, procura ressaltar que a privação sistemática de direitos e da própria dignidade dispensaria aqueles que se encontram nessa situação de todos seus deveres em relação à ordem social, uma vez que tal ordem deixaria de constituir o local no qual os sujeitos encontram sua substância ética e seu reconhecimento. Ou seja, a negação sistemática de reconhecimento engendraria a dispensa de todos os deveres em relação à ordem social. Nesse contexto, a "violência divina" do povo seria correlata do excesso de poder que lhe escapa, razão pela qual o que importaria saber, quando se trata do poder, não é se o mesmo é ou não democraticamente legítimo, mas qual o "excesso totalitário" a ele associado.

\section{Notas}

1 Segundo Jacques Rancière, ao lado de posturas que simplesmente rejeitam a democracia, haveria outras que lhe são críticas, porém não para rejeitá-la e sim para assinalar seus limites. Cf. Rancière, La haine de la démocratie, Paris, La Fabrique, 2005, p. 8.

2 Rancière ressalta que "nous ne vivons pas dans des démocraties. [...] Nous vivons dans des États de droit oligarchiques [...]" (Idem, p. 81).

3 Para uma análise dos processos de desdemocratização, ver C. Tilly, Democracy. Cambridge, Cambridge University Press, 2007.

\section{ORLANDO VILLAS BÔAS FILHO é professor da Faculdade de Direito da Universidade de São Paulo e da Universidade Presbiteriana Mackenzie. E-mail: <ovbf@usp.br>.}

